\title{
FAKTOR-FAKTOR SOSIAL EKONOMI DAN KESEHATAN MASYARAKAT KAITANNYA DENGAN MASALAH GIZI UNDERWEIGHT, STUNTED, DAN WASTED DI INDONESIA: PENDEKATAN EKOLOGI GIZI
}

\author{
(Socioeconomic and Public Health Factors Related to Underweight, Stunted, and Wasted in \\ Indonesia: Eco-nutrition Approach) \\ Dian Hani Ulfani ${ }^{1}$, Drajat Martianto ${ }^{1}$, dan Yayuk Farida Baliwati ${ }^{1 *}$ \\ 1 Departemen Gizi Masyarakat, Fakultas Ekologi Manusia, Institut Pertanian Bogor, Bogor 16680. \\ * Alamat korespondensi: Departemen Gizi Masyarakat, Fakultas Ekologi Manusia, Institut Pertanian \\ Bogor, Bogor 16680. Telp: 0251-8621258; Fax: 0251-8622276; E-mail: yayuk_gm@yahoo.com
}

\begin{abstract}
Malnutrition is an ecological problem in the sense influenced by various aspects, as explained in the framework of UNICEF (1988). Indonesia as developing country at present still faced such a problem. Eco-nutrition is important to understand related factors affecting malnutrition in Indonesia to find out more effective programs. Eco-nutrition have three key areas : public health (access to quality water, sanitation and health services), socio economic (livelihood assets) and malnutrition. The purpose of this research was to study the linkages between socioeconomic and public health factors with the problem of underweight, stunted, and wasted in Indonesia. This research was conducted using cross-sectional study design, analyzed the 424 districts/cities in Indonesia. Data prevalence of underweight, stunted, wasted, level of education and public health factors (access to quality water, hygiene behavior, utilization of Posyandu, complete immunization coverage, incidence of diarrhea, and the incidence of acute respiratory infections (ARI) obtained from Riset Kesehatan Dasar (Riskesdas ) 2007. Socio-economic data (level of poverty and GDP/capita) obtained from the Central Statistic Agency (BPS). Statistical test of Pearson correlation and stepwise linear regression method were implemented to understand factors affecting underweight, stunted, wasted and correlation among variables. The study shows that factors affecting underweight were educational level, poverty level, hygiene behavior and use of Posyandu. While factors affecting stunted were GDP/capita, education level, poverty level, hygiene behavior, and utilization of Posyandu. Factors affecting wasted were hygiene behavior, utilization of Posyandu and complete immunization.
\end{abstract}

Key words: underweight, stunted, wasted, socioeconomic factors, public health, eco-nutrition

\section{PENDAHULUAN}

Masalah gizi kurang yang terjadi di Indonesia yaitu kurang energi protein (KEP). KEP merupakan masalah gizi kurang akibat konsumsi pangan tidak cukup mengandung energi dan protein serta karena gangguan kesehatan. Manifestasi KEP ditentukan dengan pengukuran status gizi (Rimbawan \& Baliwati, 2004). Berdasarkan pengukuran status gizi terdapat kategori status gizi balita KEP yaitu underweight (BB/U), wasted atau kekurusan $(B B / T B)$, dan stunted atau pendek (TB/U). Berdasarkan Riset Kesehatan Dasar (Riskesdas) tahun 2007, sebanyak 19 provinsi mempunyai prevalensi underweight di atas prevalensi nasional. Prevalensi balita stunted, masih ditemukan di 17 provinsi di Indonesia yang memiliki prevalensi di atas prevalensi nasional yaitu
$36.8 \%$. Sebanyak 25 provinsi mempunyai prevalensi wasted di atas prevalensi nasional.

Masalah gizi merupakan masalah ekologi, karena adanya interaksi antara berbagai faktor lingkungan, baik fisik, sosial, ekonomi, budaya maupun politik (Jelliffe and Jelliffe, 1989). Secara operasional, faktor-faktor yang menjadi pencetus timbulnya masalah gizi diantaranya kemiskinan, daya beli, pengetahuan gizi, besar keluarga, kebiasaan makan, dan faktor lainnya (Suhardjo, 1989). Selain itu, dipengaruhi juga oleh status kesehatan (penyakit menular/infeksi).

Jika permasalahan kurang gizi tidak segera diatasi, maka akan berdampak pada kematian anak, penurunan kemampuan belajar, kemampuan kognitif, anggaran pencegahan dan perawatan yang meningkat dan penurunan produktivitas kerja. Oleh karena itu, perlu dia- 
nalisis faktor-faktor yang berkaitan dengan masalah kurang gizi (underweight, stunted, dan wasted) berdasarkan pendekatan ekologi gizi, sehingga permasalahan gizi kurang tersebut dapat segera dicegah dan diatasi. Tiga kata kunci dalam pendekatan ekologi gizi yaitu: 1) akses terhadap air bersih, pelayanan kesehatan; 2) aset ekonomi dan sosial sebagai cerminan akses pangan secara sosial ekonomi; 3) kurang gizi (Crahay et al. 2010; Kinabo, 2010). Faktor-faktor yang akan dianalisis adalah akses pangan secara sosial ekonomi (Produk Domestik Regional Bruto/PDRB, tingkat pendidikan dan tingkat kemiskinan), aspek kesehatan masyarakat (akses air bersih, pemanfaatan posyandu, cakupan imunisasi lengkap, kejadian diare, kejadian ISPA dan perilaku higiene*.

Penelitian ini bertujuan untuk mempelajari keterkaitan antara faktor-faktor sosial ekonomi dan kesehatan masyarakat dengan masalah gizi underweight, stunted, dan wasted di Indonesia.

\section{METODE}

\section{Desain, Waktu dan Tempat}

Penelitian ini dilaksanakan dengan meng gunakan desain penelitian cross-sectional dengan menganalisis determinan masalah gizi kurang. Data yang digunakan adalah data sekunder dari Riset Kesehatan Dasar (Riskesdas) 2007, data PDRB/kapita tanpa migas dan tingkat kemiskinan dari Badan Pusat Statistik Indonesia 2007. Pengolahan, analisis dan interpretasi data dilakukan bulan Mei - Agustus 2010 di Kampus IPB Darmaga Bogor, Jawa Barat.

\section{Jumlah dan Cara Pengambilan Contoh}

Penelitian ini menggunakan sampel yang digunakan dalam Riset Kesehatan Dasar (Riskesdas) 2007. Balita yang digunakan sebagai contoh sebanyak 79,479 yang berasal dari 424 kabupaten/kota di 32 propinsi.

\section{Jenis dan Cara Pengumpulan Data}

Data yang digunakan dalam penelitian ini seluruhnya merupakan data sekunder. Data diperoleh dari Riset Kesehatan Dasar (Riskesdas) 2007 diantaranya data masalah gizi underweight, stunted dan wasted, tingkat pendidikan, perilaku higiene, akses air bersih, pemanfaatan posyandu, cakupan imunisasi lengkap, kejadian ISPA dan kejadian diare. PDRB/kapita tanpa migas dan tingkat kemiskinan diperoleh dari Badan Pusat Statistik (BPS).

\section{Pengolahan dan Analisis Data}

Data yang diperoleh dan terkumpul dianalisa dengan menggunakan Microsoft excel 2007 for windows dan SPSS 16.0 for windows. Tahap pengolahan data pertama adalah cleaning dan pengeditan data yang sudah ada, kemudian dipilih berdasarkan variabel yang akan diteliti. Data prevalensi masalah gizi underweight, stunted, dan wasted dikategorikan berdasarkan pengkategorian prevalensi dari WHO 1995.

Tingkat pendidikan diperoleh dari persentase ibu balita yang menempuh pendidikan minimal SMA di tiap-tiap kabupaten/kota. Data PDRB/kapita tanpa migas dan tingkat kemiskinan kabupaten/kota langsung dikategorikan berdasarkan interval kelas.

Perilaku higiene ditentukan berdasarkan pertanyaan perilaku mencuci tangan memakai sabun (sebelum makan, sebelum menyiapkan makanan, setelah memegang binatang, dan setelah buang air besar), tempat buang air besar yang benar yaitu di jamban, dan memasak air sebelum dikonsumsi. Rumah tangga dikatakan memiliki perilaku higiene yang baik jika jawaban dari pertanyaan-pertanyaan tersebut "ya" (benar). Klasifikasi perilaku higiene ditetapkan berdasarkan interval kelas untuk rumah tangga yang berperilaku higiene yang baik.

Untuk akses air bersih, rumah tangga dikatakan akses air bersihnya baik jika tidak ada pencemar dalam radius $<10 \mathrm{~m}$ dari sumber air, air tidak keruh, tidak berwarna, tidak berbau, tidak berasa, dan tidak berbusa, jarak memperoleh air < $1 \mathrm{~km}$, waktu untuk memperoleh air < 30 menit dan mudah dalam memperoleh air sepanjang tahun. Klasifikasi akses air bersih ditetapkan berdasarkan interval kelas untuk rumah tangga yang memiliki akses air bersih yang baik.

Untuk pemanfaatan posyandu, dihitung persentase rumah tangga yang memanfaatkan posyandu selama 3 bulan terakhir di masingmasing kabupaten/kota. Untuk cakupan imunisasi lengkap (BCG 1 kali, polio 3 kali, DPT 3 kali, campak 1 kali dan hepatitis 3 kali), dilihat dari persentase balita yang diimunisasi lengkap di masing-masing kabupaten/kota.

Kejadian ISPA dan diare ditentukan oleh pernah tidaknya didiagnosis menderita ISPA dan diare dalam 1 bulan terakhir oleh tenaga kesehatan. Kemudian dihitung persentase balita menderita diare dalam 1 bulan terakhir pada setiap kabupaten/kota.

Setelah didapatkan persentase dari masing-masing variabel, dilakukan pengkategori- 
an berdasarkan interval kelas dengan perhitungan sebagai berikut (Slamet, 1993):

Interval kelas $=\frac{\text { Range }}{\text { Jumlah kelas }}$

Range $=$ skor tertinggi - skor terendah

Tabel 1. Cara Pengklasifikasian Variabel

\begin{tabular}{|c|c|c|}
\hline No. & Variabel & Klasifikasi \\
\hline 1 & Underweight & $\begin{array}{ll}\text { 1. } & \text { Rendah }(<10) \\
2 . & \text { Sedang }(10-19) \\
\text { 3. } & \text { Tinggi }(20-29) \\
\text { 4. } & \text { Sangat tinggi }(\geq 30) \\
\end{array}$ \\
\hline 2 & Stunted & $\begin{array}{ll}\text { 1. } & \text { Rendah }(<20) \\
\text { 2. } & \text { Sedang }(20-29) \\
\text { 3. } & \text { Tinggi }(30-39) \\
\text { 4. } & \text { Sangat tinggi } \geq 40) \\
\end{array}$ \\
\hline 3 & Wasted & $\begin{array}{ll}\text { 1. } & \text { Rendah }(<5) \\
\text { 2. } & \text { Sedang }(5-9) \\
\text { 3. } & \text { Tinggi }(10-14) \\
\text { 4. } & \text { Sangat tinggi }(\geq 15) \\
\end{array}$ \\
\hline 4 & $\begin{array}{l}\text { Tingkat } \\
\text { Pendidikan }\end{array}$ & $\begin{array}{ll}\text { 1. } & \text { Rendah }(<17 \%) \\
\text { 2. } & \text { Sedang }(17-34.9 \%) \\
\text { 3. } & \text { Tinggi }(>34.9 \%)\end{array}$ \\
\hline 5 & $\begin{array}{l}\text { PDRB/kapita } \\
\text { wilayah }\end{array}$ & $\begin{array}{l}\text { 1. Rendah }(<94,832,000) \\
\text { 2. Sedang }(94,832,000-188,535,000) \\
\text { 3. Tinggi }(>188,535,000)\end{array}$ \\
\hline 6 & $\begin{array}{l}\text { Tingkat } \\
\text { kemiskinan }\end{array}$ & $\begin{array}{ll}1 \text { 1. } & \text { Rendah }(<10 \%) \\
\text { 2. } & \text { Sedang }(10-20 \%) \\
\text { 3. } & \text { Tinggi }(>20 \%) \\
\end{array}$ \\
\hline 7 & $\begin{array}{l}\text { Perilaku } \\
\text { sehat }\end{array}$ & $\begin{array}{l}\text { 1. Rendah }(<19.8 \%) \\
\text { 2. Sedang }(19.9-39.6 \%) \\
\text { 3. Tinggi }(>39.6 \%)\end{array}$ \\
\hline 8 & $\begin{array}{l}\text { Akses air } \\
\text { bersih }\end{array}$ & $\begin{array}{ll}\text { 1. } & \text { Rendah }(<33 \%) \\
\text { 2. } & \text { Sedang }(33-62 \%) \\
\text { 3. } & \text { Tinggi }(>62 \%) \\
\end{array}$ \\
\hline 9 & Posyandu & $\begin{array}{ll}\text { 1. } & \text { Rendah }(<38.6 \%) \\
\text { 2. Sedang }(38.6-68.3 \%) \\
\text { 3. } \text { Tinggi }(>68.3 \%)\end{array}$ \\
\hline 10 & Imunisasi & $\begin{array}{ll}\text { 1. } & \text { Rendah }(<25.7 \%) \\
\text { 2. Sedang }(25.7-51.5 \%) \\
\text { 3. Tinggi }(>51.5 \%)\end{array}$ \\
\hline 11 & ISPA & $\begin{array}{l}\text { 1. Rendah }(<29.4 \%) \\
\text { 2. Sedang }(29.4-58.4 \%) \\
\text { 3. Tinggi }(>58.4 \%)\end{array}$ \\
\hline 12 & Diare & $\begin{array}{ll}\text { 1. } & \text { Rendah }(<31 \%) \\
\text { 2. Sedang }(31-61.4 \%) \\
\text { 3. Tinggi }(>61.4 \%)\end{array}$ \\
\hline
\end{tabular}

Analisis hubungan variabel bebas dan tidak bebas menggunakan uji korelasi Pearson. Besarnya pengaruh variabel bebas karakteristik sosial ekonomi, perilaku higiene serta akses air bersih, dan status kesehatan terhadap variabel tidak bebas masalah gizi underweight, stunt ed, dan wasted diuji dengan uji analisis regresi linear berganda metode stepwise.

\section{HASIL DAN PEMBAHASAN}

\section{Prevalensi Kurang Gizi di Indonesia.}

Berdasarkan hasil penelitian, lebih dari separuh kabupaten/kota di Indonesia memiliki prevalensi underweight (BB/U) sedang berdasarkan standar klasifikasi masalah gizi WHO (1995). Rata-rata prevalensi underweight adalah $20.27 \pm 7.3182 \%$. Kabupaten/kota yang memiliki prevalensi underweight tertinggi adalah Kabupaten Aceh Tenggara, Propinsi Nangroe Aceh Darusalam (48.8\%).

Prevalensi stunted (TB/U) kabupaten/ kota di Indonesia, sebagian besar berada pada tingkat sangat tinggi (42.7\%) dengan rata-rata prevalensi stunted adalah $38.45 \pm 9.11 \%$. Kabupaten/kota yang memiliki prevalensi stunted tertinggi adalah Kabupaten Seram Bagian Timur (67.9\%), Propinsi Maluku. Menurut Salimar et al. (2009), prevalensi balita pendek tertinggi berada di pedesaan (65.1\%), karena sebagian besar balita berada di pedesaan di empat wilayah (Sumatera, Bali dan Indonesia Timur, Kalimantan dan Sulawesi) di Indonesia.

Sebagian besar kabupaten/kota memiliki prevalensi wasted (BB/TB) sangat tinggi, yaitu sebanyak 206 kabupaten/kota (48.6\%). Berdasarkan Riskesdas 2007, prevalensi wasted nasional adalah $13.6 \%$, tetapi pada penelitian ini ditemukan kabupaten/kota yang mempunyai prevalensi stunted di atas prevalensi nasional dan lebih besar dari 15\% (WHO 1995). Ratarata prevalensi stunted adalah $15.21 \pm 5.99 \%$.

Target Millenium Development Goals (MDGs) Indonesia tahun 1990-2015 adalah menurunkan proporsi penduduk yang menderita kelaparan menjadi setengahnya antara tahun 1990 sampai tahun 2015. Indikator yang dipakai dalam pencapaian target tersebut adalah persentase anak-anak berusia di bawah 5 tahun yang mengalami gizi kurang (moderate underweight) mencapai 18.5\% (Bappenas, 2007). Target Rencana Pembangunan Jangka Menengah (RPJM) Indonesia tahun 2015 untuk program perbaikan gizi adalah $20 \%$. Bila dibandingkan dengan target-target tersebut, maka secara nasional Indonesia telah melampaui target. Hal tersebut terlihat pada prevalensi sebagian kabupaten/kota berada pada tingkat sedang (10-19\%).

\section{PDRB/kapita}

PDRB/kapita yang dipakai dalam penelitian ini adalah PDRB yang berasal dari sektor usaha: pertanian, industri pengolahan, listrik, gas, dan air bersih, bangunan (konstruksi), perdagangan, hotel dan restoran, pengangkutan dan komunikasi, keuangan, persewaan dan jasa perusahaan, dan jasa-jasa termasuk pelayanan pemerintah, kecuali sektor usaha penggalian dan pertambangan. Sebagian besar kabupaten/kota (72.1\%) memiliki PDRB/kapita yang rendah, dimana nilai PDRB/kapitanya ku- 
rang dari Rp 12,128,150. Rata-rata kabupaten/ kota memiliki PDRB/kapita sebesar Rp $10,999,150 \pm 8502.22$. Perbedaan nilai PDRB di kabupaten/kota dikarenakan adanya perbedaan sumber daya alam dan pemanfaatannya dalam mendukung kegiatan perekonomian di wilayah tersebut.

\section{Tingkat kemiskinan}

Sebanyak 39.2\% kabupaten/kota di Indonesia tingkat kemiskinannya tinggi. Rata-rata tingkat kemiskinan di kabupaten/kota di Indonesia sebesar $18.41 \pm 10.46 \%$. Masalah kemiskinan akan berdampak pada kurangnya akses masyarakat terhadap pemenuhan kebutuhan pangan maupun pelayanan kesehatan. Jumlah orang miskin mencerminkan kelompok yang tidak mempunyai akses pangan, jika persentasenya lebih dari 20\%, maka akses pangannya termasuk dalam kategori rendah. Kemiskinan merupakan indikator ketidakmampuan untuk mendapatkan cukup pangan, karena rendahnya kemampuan daya beli atau hal ini mencerminkan ketidakmampuan untuk memenuhi kebutuhan dasar, seperti, makanan, pakaian, perumahan, pendidikan, dan lain-lain (BKP, 2008).

\section{Tingkat pendidikan}

Tingkat pendidikan ibu yang rendah masih terdapat di 193 kabupaten/kota di Indonesia (Tabel 4). Hal tersebut sejalan dengan penelitian Permanasari et al pada tahun 2009, persentase pendidikan ibu yang kurang dari SLTA adalah sebesar $49.4 \%$.

Menurut Atmarita dan Fallah (2004) tingkat pendidikan yang lebih tinggi akan memudahkan seseorang untuk mengimplementasikan pengetahuannya dalam perilaku khususnya dalam hal kesehatan dan gizi. Dengan demikian, pendidikan ibu yang relatif rendah akan berkaitan dengan sikap dan tindakan ibu dalam menangani masalah kurang gizi pada anak balitanya.

\section{Akses terhadap kesehatan}

\section{Akses air bersih}

Akses air bersih rumah tangga tergolong sedang (67.2\%) atau hanya 33-62\% rumah tangga di wilayah kabupaten/kota yang memiliki akses air bersih dengan rata-rata $52.35 \pm 14.27$ \%. Jika dilihat dari indikator akses air bersih, masih terdapat kabupaten/kota yang sekitar $50 \%$ rumah tangganya memiliki sumber air berdekatan dengan pencemar (jarak kurang dari $10 \mathrm{~m})$, kemudian masih terdapat rumah tangga yang kesulitan memperoleh air sepanjang tahun.

\section{Pemanfaatan posyandu}

Pemanfaatan posyandu di Indonesia masih berada pada tingkat sedang, dimana 38-68\% rumah tangga memanfaatkan posyandu dalam 3 bulan terakhir. Posyandu dapat dimanfaatkan oleh penduduk sebagai sarana untuk memantau pertumbuhan anak. Penimbangan bulanan yang dilaksanakan di posyandu merupakan sarana melakukan aksi koreksi secara dini jika terjadi gangguan pertumbuhan terhadap anak sehingga tidak berkembang menjadi gizi kurang atau gizi buruk.

\section{Cakupan imunisasi lengkap}

Sama halnya dengan pemanfaatan posyandu, pemanfaatan imunisasi berada pada tingkat sedang. Terdapat 204 kabuapaten/kota di Indonesia, hanya sekitar 26-52\% rumahtangga yang memanfaatkan imunisasi lengkap (BCG 1 kali, polio 3 kali, DPT 3 kali, campak 1 kali dan Hepatitis B 3 kali). Hasil penelitian menunjukkan jenis imunisasi yang umumnya belum lengkap diberikan kepada balita adalah imunisasi DPT, hepatitis B, polio dan campak.

\section{Tingkat Kesehatan}

Status kesehatan penduduk di suatu wilayah dapat dilihat dari kejadian penyakit infeksi seperti infeksi saluran pernapasan akut (ISPA) dan diare. Sebagian besar kabupaten/kota di Indonesia memiliki tingkat kejadian ISPA dan diare yang rendah. Rata-rata kejadian ISPA dan diare berturut-turut adalah $11.77 \pm 7.45 \%$ dan $17.13 \pm 11.61 \%$.

\section{Faktor-faktor yang Mempengaruhi Masalah Kurang Gizi}

\section{Faktor-faktor yang mempengaruhi under- weight}

Berdasarkan analisis korelasi Pearson, diketahui bahwa faktor-faktor yang berhubungan dengan underweight adalah PDRB/ kapita, tingkat pendidikan, tingkat kemiskinan, perilaku higiene, akses air bersih, pemanfaatan posyandu, imunisasi lengkap, dan kejadian diare.

Dengan analisis regresi linier (step-wise regression) diketahui pengaruh dari setiap faktor tersebut. Berdasarkan hasil analisis regresi diketahui bahwa tingkat pendidikan, tingkat kemiskinan, perilaku higiene, dan pemanfaatan posyandu berpengaruh terhadap underweight $(\mathrm{BB} / \mathrm{U})$. Persamaan liniernya adalah sebagai berikut:

\footnotetext{
$Y_{1}=27.593-0.107 X_{2}+0.123 X_{3}-0.170 X_{4}-0.056 X_{6}$ $\mathrm{Y}_{1}$ : prevalensi underweight $(\mathrm{BB} / \mathrm{U})$

$\mathrm{X}_{2}$ : tingkat pendidikan

$\mathrm{X}_{3}$ : tingkat kemiskinan
} 
$\mathrm{X}_{4}$ : perilaku higiene

$\mathrm{X}_{6}$ : pemanfaatan posyandu

Tabel 2. Faktor yang Berhubungan dan Faktor yang Berpengaruh pada Underweight

\begin{tabular}{|c|c|c|c|}
\hline \multirow[b]{2}{*}{ Variabel } & \multicolumn{3}{|c|}{ Prevalensi Underweight } \\
\hline & $\begin{array}{l}\text { Koefisien } \\
\text { korelasi (r) }\end{array}$ & $\begin{array}{c}\text { Koefisien } \\
\text { regresi }\end{array}$ & $\begin{array}{l}\text { Sig. } \\
\text { regresi }\end{array}$ \\
\hline PDRB/kapita $\left(\mathrm{X}_{1}\right)$ & $-0.197^{* *}$ & & \\
\hline $\begin{array}{l}\text { Tingkat pendidikan } \\
\left(X_{2}\right)\end{array}$ & $-0.391^{* *}$ & -0.107 & 0.000 \\
\hline $\begin{array}{l}\text { Tingkat kemiskinan } \\
\left(\mathrm{X}_{3}\right)\end{array}$ & $0.342^{* * *}$ & 0.123 & 0.000 \\
\hline $\begin{array}{l}\text { Perilaku higiene } \\
\left(\mathrm{X}_{4}\right)\end{array}$ & $-0.393^{\prime \prime}$ & -0.170 & 0.000 \\
\hline $\begin{array}{l}\text { Akses air bersih } \\
\left(X_{5}\right)\end{array}$ & $-0.097^{*}$ & & \\
\hline $\begin{array}{l}\text { Pemanfaatan } \\
\text { posyandu }\left(\mathrm{X}_{6}\right)\end{array}$ & $-0.160^{* *}$ & 0.056 & 0.007 \\
\hline $\begin{array}{l}\text { Imunisasi lengkap } \\
\left(\mathrm{X}_{7}\right)\end{array}$ & $-0.272^{* *}$ & & \\
\hline Kejadian ISPA $\left(\mathrm{X}_{8}\right)$ & -0.045 & & \\
\hline Kejadian diare $\left(X_{9}\right)$ & $0.114^{*}$ & & \\
\hline
\end{tabular}

**. Hubungan nyata $(p<0.01)$

*. Hubungan nyata $(p<0.05)$

\section{Faktor-faktor yang mempengaruhi stunted}

Berdasarkan analisis korelasi Pearson, diketahui bahwa faktor-faktor yang berhubungan dengan stunted adalah PDRB/kapita, tingkat pendidikan, tingkat kemiskinan, perilaku higiene, pemanfaatan posyandu, imunisasi lengkap dan kejadian diare.

Tabel 3. Faktor yang Berhubungan dan Faktor yang Berpengaruh terhadap Stunted

\begin{tabular}{|c|c|c|c|}
\hline \multirow[b]{2}{*}{ Variabel } & \multicolumn{3}{|c|}{ Prevalensi Stunted } \\
\hline & $\begin{array}{c}\text { Koefisien } \\
\text { korelasi (r) }\end{array}$ & $\begin{array}{l}\text { Koefisien } \\
\text { regresi }\end{array}$ & $\begin{array}{l}\text { Sig. } \\
\text { regresi }\end{array}$ \\
\hline PDRB/kapita $\left(X_{1}\right)$ & $-0.294^{* *}$ & $-4.347 \times 10^{-8}$ & 0.005 \\
\hline $\begin{array}{l}\text { Tingkat pendidikan } \\
\left(\mathrm{X}_{2}\right)\end{array}$ & $-0.388^{* *}$ & -0.129 & 0.000 \\
\hline $\begin{array}{l}\text { Tingkat kemiskinan } \\
\left(\mathrm{X}_{3}\right)\end{array}$ & $0.326^{* *}$ & 0.116 & 0.007 \\
\hline Perilaku higiene $\left(X_{4}\right)$ & $-0.320^{* *}$ & -0.143 & 0.000 \\
\hline Akses air bersih $\left(X_{5}\right)$ & -0.003 & & \\
\hline $\begin{array}{l}\text { Pemanfaatan } \\
\text { posyandu }\left(\mathrm{X}_{6}\right)\end{array}$ & $0.121^{*}$ & -0.061 & 0.022 \\
\hline $\begin{array}{l}\text { Imunisasi lengkap } \\
\left(X_{7}\right)\end{array}$ & $-0.153^{* *}$ & & \\
\hline Kejadian ISPA $\left(\mathrm{X}_{8}\right)$ & 0.003 & & \\
\hline Kejadian diare $\left(X_{9}\right)$ & $0.144^{* *}$ & & \\
\hline
\end{tabular}

Dengan analisis regresi linier (stepwise regression) diketahui pengaruh dari setiap faktor tersebut. Berdasarkan hasil analisis regresi linier tersebut dapat diketahui bahwa PDRB/kapita, tingkat pendidikan, dan perilaku higiene berpengaruh negatif terhadap stunted, sedangkan tingkat kemiskinan berpengaruh positif terhadap stunted. Kondisi ini menunjukkan semakin tinggi persentase penduduk yang berperilaku higiene, penduduk yang berpendidikan tinggi dan tingginya PDRB/kapita wilayah, maka semakin rendah prevalensi stunted, semakin tinggi tingkat kemiskinan maka prevalensi stunted semakin meningkat. Dengan persamaan liniernya seba- gai berikut:

$$
\begin{aligned}
Y_{2}= & 48.037-\left(4.347 \times 10^{-8}\right) \mathrm{X}_{1}-0.129 \mathrm{X}_{2}+0.116 \mathrm{X}_{3} \\
& -0.143 \mathrm{X}_{4}-0.061 \mathrm{X}_{6} \\
& \mathrm{Y}_{2}: \text { prevalensi stunted } \\
& \mathrm{X}_{1}: \text { PDRB } / \text { kapita } \\
& \mathrm{X}_{2}: \text { tingkat pendidikan } \\
& \mathrm{X}_{3}: \text { tingkat kemiskinan } \\
& \mathrm{X}_{4}: \text { perilaku higiene } \\
& \mathrm{X}_{6}: \text { pemanfaatan posyandu }
\end{aligned}
$$

\section{Faktor-faktor yang mempengaruhi wasted}

Wasted (BB/TB) dapat menjelaskan proses yang mengarah pada terjadinya kehilangan berat badan, sebagai konsekuensi dari kelaparan akut dan atau penyakit berat dengan nilai pengukuran z skornya kurang dari -2.0 SD sampai dengan -3,0 SD (Riyadi 2001). Indeks BB/TB ini merupakan indikator yang baik untuk menilai status gizi saat ini. Berikut akan dijelaskan mengenai faktor penyebab wasted (BB/TB).

Tabel 4. Faktor yang Berhubungan dan Faktor yang berpengaruh Terhadap Wasted

\begin{tabular}{lrcr}
\hline \multirow{1}{*}{ Variabel } & \multicolumn{3}{c}{ Prevalensi Wasted } \\
\cline { 2 - 4 } & $\begin{array}{c}\text { Koefisien } \\
\text { korelasi }(r)\end{array}$ & $\begin{array}{c}\text { Koefisien } \\
\text { regresi }\end{array}$ & $\begin{array}{c}\text { Sig. } \\
\text { regresi }\end{array}$ \\
\hline PDRB/kapita $\left(X_{1}\right)$ & 0.018 & & \\
Tingkat pendidikan & -0.081 & & \\
$\left(X_{2}\right)$ & & & \\
Tingkat kemiskinan & 0.084 & & \\
$\left(X_{3}\right)$ & $-0.241^{* * *}$ & -0.094 & 0.000 \\
Perilaku higiene $\left(X_{4}\right)$ & -0.091 & & \\
Akses air bersih $\left(X_{5}\right)$ & $-0.225^{* *}$ & -0.062 & 0.002 \\
Pemanfaatan & & & \\
posyandu $\left(X_{6}\right)$ & $-0.220^{* *}$ & -0.045 & 0.010 \\
Imunisasi lengkap & -0.073 & & \\
$\left(X_{7}\right)$ & 0.022 & & \\
Kejadian ISPA $\left(X_{8}\right)$ & & & \\
Kejadian diare $\left(X_{9}\right)$ & &
\end{tabular}

**. Hubungan nyata $(p<0.01)$

*. Hubungan nyata $(p<0.05)$

Berdasarkan analisis korelasi Pearson, diketahui bahwa faktor-faktor yang berhubungan dengan wasted adalah perilaku higiene, pemanfaatan posyandu, dan imunisasi lengkap. Berdasarkan hasil analisis regresi linier dapat diketahui bahwa ketiga faktor tersebut berpengaruh negatif terhadap prevalensi wasted. Artinya semakin tinggi perilaku higiene, pemanfaatan posyandu dan cakupan imunisasi lengkap, maka semakin rendah prevalensi wasted. Persamaan linier dari model regresinya sebagai berikut: 


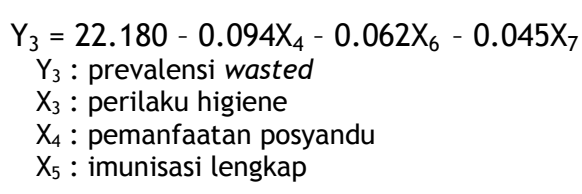

Berdasarkan hasil penelitian, masalah gizi akut maupun kronis masih terjadi di Indonesia. Masalah gizi akut diperlihatkan oleh masalah underweight dan wasted, sedangkan masalah gizi kronis ditunjukkan oleh masalah stunted. Secara keseluruhan, faktor-faktor yang berhubungan dan berpengaruh terhadap ketiga masalah gizi (underweight, stunted, dan wasted) dapat dilihat pada tabel 38. Faktor yang bersama-sama mempengaruhi ketiga masalah gizi adalah perilaku higiene dan pemanfaatan posyandu.

Faktor perilaku higiene berpengaruh penting terhadap masalah gizi meskipun faktor ini bukan merupakan faktor yang secara langsung berpengaruh terhadap masalah kurang gizi. Perilaku higiene berpengaruh langsung terhadap penyakit infeksi yang umumnya dialami oleh sebagian besar balita, khususnya penyakit infeksi diare dan ISPA. Kedua penyakit ini berpengaruh langsung terhadap status gizi balita. Seorang balita yang menderita penyakit infeksi nafsu makannya cenderung berkurang sehingga asupan gizinya pun berkurang. Jika berlangsung dalam waktu yang lama dengan frekuensi berkali-kali maka akan berdampak pada kurang gizi.

Sementara itu, pemanfaatan posyandu juga memegang peran penting terhadap masalah gizi. Posyandu merupakan salah satu sarana untuk memantau kesehatan dan pertumbuhan balita. Masalah gizi yang terjadi pada balita akan lebih dideteksi secara dini jika pertumbuhan balita dipantau secara rutin melalui posyandu. Oleh karena itu, ibu yang secara rutin memantau pertumbuhan balitanya akan lebih mampu memperbaiki masalah gizi secara dini, sehingga masalah tersebut tidak menjadi lebih parah.

Kedua faktor di atas dipengaruhi pula oleh faktor-faktor sosial ekonomi karena pada hakikatnya perilaku higiene dan pemanfaatan posyandu merupakan pola asuh kesehatan terhadap balita. Pola asuh ibu terhadap balita dibentuk dari pengetahuan ibu yang diimplementasikan dalam kehidupan sehari-harinya. Pengetahuan didapatkan dari proses pendidikan dan kemampuan mengakses informasi. Oleh karena itu, akses terhadap pendidikan harus ditingkatkan. Salah satunya dengan meningkatkan kesejahteraan dan perekonomian penduduk karena tingkat kesejahteraan dan perekonomian yang rendah merupakan salah satu hambatan dalam menempuh pendidikan yang lebih tinggi.

Tabel 5. Faktor-faktor yang Berhubungan dan Berpengaruh terhadap Underweight, Wasted dan Stunted

\begin{tabular}{|c|c|c|c|}
\hline \multirow{2}{*}{ Variabel } & \multicolumn{3}{|c|}{ Masalah Gizi } \\
\hline & Underweight & Stunted & Wasted \\
\hline PDRB/kapita & $x x x$ & $x x x^{*}$ & - \\
\hline Tingkat kemiskinan & $x x^{*}$ & $x x^{*}$ & - \\
\hline Tingkat pendidikan & $x x^{*}$ & $x x^{*}$ & - \\
\hline Perilaku higiene & $x x x^{*}$ & $x x^{*}$ & $x x^{*}$ \\
\hline Akses air bersih & $x x$ & - & - \\
\hline $\begin{array}{l}\text { Pemanfaatan } \\
\text { posyandu }\end{array}$ & $x x^{*}$ & $x x^{*}$ & $x x^{*}$ \\
\hline $\begin{array}{l}\text { Cakupan imunisasi } \\
\text { lengkap }\end{array}$ & $x x x$ & $x x x$ & $x x x^{*}$ \\
\hline Kejadian diare & $x x$ & $x x x$ & - \\
\hline Kejadian ISPA & - & - & - \\
\hline
\end{tabular}

$\begin{array}{ll}\mathrm{xxx} & \text { : berhubungan sangat kuat } \\ \mathrm{xx} & \text { : berhubungan kuat } \\ & : \text { berpengaruh }\end{array}$

\section{KESIMPULAN}

Sebagian besar kabupaten/kota di Indonesia memiliki prevalensi underweight sedang, namun prevalensi stunted dan wasted yang sangat tinggi. Berdasarkan kareksteristik sosial ekonomi, sebagian besar kabupaten/kota di Indonesia memiliki PDRB/kapita yang rendah, sebagian kabupaten/kota di Indonesia memiliki tingkat pendidikan rendah. Rata-rata tingkat kemiskinan kabupaten/kota di Indonesia adalah $18.41 \pm 10.46 \%$. Perilaku higiene kabupaten/ kota di Indonesia tergolong masih rendah. Sementara itu, akses air bersih kabupaten/kota di Indonesia tergolong rendah. Dalam hal pemanfaatan posyandu, rata-rata sekitar $64.97 \pm$ $14.89 \%$ rumah tangga di kabupaten/kota yang memanfaatkan posyandu. Cakupan imunisasi lengkap kabupaten/kota di Indonesia rataratanya adalah $33.0766 \pm 17.15 \%$ balita yang mendapatkan imunisasi lengkap. Kemudian rata-rata kejadian ISPA dan diare di kabupaten/kota Indonesia adalah $17.13 \pm 11.61 \%$ dan $11.77 \pm 7.45 \%$.

Faktor yang berhubungan nyata terhadap underweight adalah PDRB/kapita, tingkat pendidikan, tingkat kemiskinan, perilaku higiene, akses air bersih, pemanfaatan posyandu, imunisasi lengkap, dan kejadian diare. Faktor yang berhubungan nyata terhadap stunted adalah PDRB/kapita, tingkat pendidikan, perilaku higiene, pemanfaatan posyandu, imunisasi lengkap, dan kejadian diare. Faktor yang berhubungan nyata terhadap wasted adalah perilaku higiene, pemanfaatan posyandu, dan imunisasi lengkap. 
Berdasarkan uji regresi linier, faktor yang berpengaruh terhadap underweight adalah tingkat pendidikan, tingkat kemiskinan, perilaku higiene dan pemanfaatan posyandu. Faktor ekologi yang berpengaruh terhadap stunted adalah PDRB/kapita, tingkat pendidikan, tingkat kemiskinan, perilaku higiene, dan pemanfaatan posyandu. Faktor ekologi yang berpengaruh terhadap wasted adalah perilaku higiene, pemanfaatan posyandu dan imunisasi lengkap.

Faktor ekologi yang sama-sama berpengaruh terhadap ketiga masalah gizi (underweight, stunted dan wasted) adalah perilaku higiene dan pemanfaatan posyandu.

\section{DAFTAR PUSTAKA}

Alhanannasir. 1999. Hubungan konsumsi makanan dan morbiditas dengan status gizi anak balita transmigran. Tesis Magister Sekolah Pasca Sarjana, Institut Pertanian Bogor, Bogor.

Almatsier S. 2004. prinsip Dasar Ilmu Gizi. PT Gramedia Pustaka Utama, Jakarta.

Atmarita \& Fallah TS. 2004. Analisis Situasi Gizi dan Kesehatan Masyarakat. Widyakarya Nasional pangan dan gizi VIII. LIPI, Jakarta.

. 2009. Produk Domestik Regional Bruto Kabupaten/Kota Di Indonesia 20042008. Badan Pusat Statistik, Jakarta.

Crahay P et al. 2010. The threats of climate change on undernutrition - a neglected issue that requires further analysis and urgent actions. SCN News, 38(2010), 410.

Jelliffe \& Jelliffe. 1989. Community Nutritional Assessment. Oxford University Press, Oxford.

Kinabo J. 2010. Food security, adequate care and environment quality: Development and testing of eco-nutrition guidelines for community actions in the context of climate change. SCN News, 38(2010) 87.
Manary MJ \& Solomons NW. 2008. Aspek Kesehatan Masyarakat pada Gizi Kurang. Gibney MJ et al (Eds.), Gizi Kesehatan Masyarakat. EGC, Jakarta.

Rasmaliah. 2004. Infeksi Saluran pernapasan akut (ISPA) dan penanggulangannya. Fakultas Kesehatan Masyarakat, Universitas Sumatera Utara.

Rimbawan \& Yayuk B. 2004. Masalah pangan dan gizi. Dalam Yayuk B et al. (Eds.), Pengantar Pangan dan Gizi. Penebar Swadaya, Jakarta.

Riyadi H. 2001. Metode Penilaian Status Gizi. Fakultas Pertanian, Institut Pertanian Bogor, Bogor.

Salimar et al. 2009. Karakteristik masalah pendek (stunting) pada balita di seluruh wilayah Indonesia. Jurnal Penelitian Gizi dan Makanan, 3(67), 63-74.

Santoso S \& Ranti AL. 1999. Kesehatan dan Gizi. PT Rineka Cipta, Jakarta.

Scortino R. 2007. Menuju Kesehatan Madani. Gadjah Mada University Press, Yogyakarta.

Slamet. 1993. Analisis Kuantitatif untuk Data Sosial. Dabara Publisher, Solo.

Yunarko A. 2007. Analisis pengaruh tingkat investasi, pendapatan asli daerah dan tenaga kerja terhadap PDRB Jawa Tengah. Skripsi Sarjana, Fakultas Ekonomi, Universitas Negeri Semarang, Semarang.

Zulkifli. 2003. Posyandu dan kader kesehatan. Fakultas Kesehatan Masyarakat, Universitas Sumatera Utara.

Zuraida R. 2009. Pengaruh penyuluhan gizi dan pemanfaatan pekarangan terhadap tingkat pengetahuan, sikap dan perilaku gizi ibu dan status gizi anak balita. Tesis Magister Sekolah Pasca Sarjana, Institut Pertanian Bogor, Bogor. 